\title{
KEARIFAN LOKAL DALAM LEKSIKON PUJI-PUJIAN RITUAL NGAJI RASA
}

\section{LOCAL WISDOM IN THE LEXICON OF RITUAL BLESSING NGAJI RASA}

\author{
S Mila1a \\ ${ }^{1}$ Program Studi Bahasa dan Sastra Indonesia, Fakultas Pendidikan Bahasa dan Seni, \\ Universitas Pendidikan Indonesia, Jl. Setiabudi No. 229 Bandung, Jawa Barat 40154 \\ a Korespondensi: Syamsiyatul Mila, Email: milasyamsi@yahoo.com \\ (Diterima: 10-02-2017; Ditelaah: 10-02-2017; Disetujui: 24-04-2017)
}

\begin{abstract}
The research was distributed by the pros and cons of the Dayak community to the existence of Hindu-Buddhist Earth Segandu Indramayu (SDHBBSI) in Indramayu neighborhoods deemed heretical. The existence of a SDHBBSI community overview considered one eye turned out to have a culture that values the sublime. These values are reflected in the arrayarray Ngaji Rasa the rites of blessing a sense held each night Friday Kliwon as one form of prayer. As for the problems of the staple in this research are (1) the structure of the text, (2) a reference lexicon, and (3) local wisdom values contained in the Ngaji Rasa of ritual blessing. In doing research in the field, this research is limited to three text praises the ritual of Ngaji Rasa. This research was used to support the anthropolinguistic approach with a model ethnography of communication. The technique of data collection in this research is the observation and interviews, participants are not structured. The technique of data analysis is performed by doing a text structure analysis based on the praises, analyzes the reference lexicon, and uncover local wisdom values contained in the Ngaji Rasa of ritual blessing. In this study, obtained five repetitions of the lexicon, 10 isotopes are divided into three themes in the analysis of the motives of the structure of the text. Lexicon reference retrieved as many as seven, namely application, Godhead, natural, kinship, places, activities, and advice. Lexicon containing wisdom in accordance with Javanese view of life, namely the microcosm and macrocosm showed a value of harmony in the praise.
\end{abstract}

Keywords: anthropolinguistics, blessing, ethnography, local wisdom.

\begin{abstract}
ABSTRAK
Penelitian ini dilatarbelakangi oleh adanya pro dan kontra terhadap keberadaan komunitas Suku Dayak Hindu Budha Bumi Segandu Indramayu (SDHBBSI) di lingkungan masyarakat Indramayu yang dianggap sesat. Keberadaan komunitas SDHBBSI yang sekilas dipandang sebelah mata ini ternyata memiliki nilai-nilai budaya yang luhur. Nilai-nilai tersebut tercermin pada larik-larik puji-pujian ritual Ngaji Rasa yang diadakan setiap malam Jumat Kliwon sebagai salah satu bentuk sembahyang. Adapun permasalahan pokok dalam penelitian ini adalah (1) struktur teks, (2) referensi leksikon, dan (3) nilai-nilai kearifan lokal yang terkandung dalam puji-pujian ritual Ngaji Rasa. Dalam melakukan penelitian di lapangan, penelitian ini dibatasi pada tiga teks puji-pujian ritual Ngaji Rasa. Untuk menunjang penelitian ini digunakan pendekatan antropolinguistik dengan model etnografi komunikasi. Teknik pengumpulan data dalam penelitian ini adalah observasi partisipan, dan wawancara tidak berstruktur. Teknik analisis data dilakukan dengan melakukan analisis berdasarkan struktur teks puji-pujian, menganalisis referensi leksikon, dan mengungkap nilai-nilai kearifan lokal yang terkandung di dalam puji-pujian ritual Ngaji Rasa. Dalam penelitian ini, diperoleh lima pengulangan leksikon yang kuat, 10 isotopi yang dibagi menjadi tiga motif tema dalam analisis struktur teks. Referensi leksikon diperoleh sebanyak tujuh, yakni permohonan, ketuhanan, alam, kekerabatan, tempat, aktifitas, dan nasihat. Leksikon yang
\end{abstract}


mengandung kearifan sesuai dengan pandangan hidup orang Jawa, yakni mikrokosmos dan makrokosmos menunjukkan adanya nilai harmoni dalam puji-pujian.

Kata kunci: antropolinguistik, etnografi, kearifan lokal, puji-pujian.

Mila S. 2017. Kearifan lokal dalam leksikon puji-pujian ritual ngaji rasa. Jurnal Sosial Humaniora 8(1): 75-84.

\section{PENDAHULUAN}

Kebudayaan lahir, tumbuh, dan berkembang dalam masyarakat. Segala sesuatu yang terdapat dalam masyarakat ditentukan oleh kebudayaan yang dimiliki oleh masyarakat itu sendiri yang meliputi kepercayaan, adatistiadat, kesenian, dan norma-norma.

Suatu kebudayaan merupakan ciri khas dari masyarakat tertentu, salah satu unsur penting yang paling membedakan suatu kebudayaan adalah bahasa. Bahasa dapat mencerminkan suatu kebudayaan masyarakat tertentu, bahasa juga merupakan salah satu isi pokok dari tiap kebudayaan di dunia (Koentjaraningrat 2009). Sementara itu, Kridalaksana (2001) berpendapat bahwa bahasa adalah sistem tanda bunyi yang disepakati untuk digunakan oleh para anggota kelompok masyarakat tertentu dalam bekerja sama, berkomunikasi, dan mengidentifikasi diri. Melalui bahasa seseorang dapat mengungkapkan persepsi, konsepsi, dan keyakinan. Salah satu contoh penggunaan bahasa sebagai alat untuk mengungkapkan persepsi, konsepsi, dan keyakinan adalah puji-pujian yang dilantunkan oleh komunitas Suku Dayak Hindu Budha Bumi Segandhu Indramayu (SDHBBSI) di Desa Krimun, Kecamatan Losarang, Kabupaten Indramayu. Puji-pujian tersebut digunakan sebagai bentuk ungkapan persembahan terhadap ajaran yang dianut.

Sebagai komunitas budaya, komunitas SDHBBSI ini cukup menimbulkan pro dan kontra atas keberadaannya yang muncul sejak tahun 1970-an. Komunitas SDHBBSI ini bukanlah suatu komunitas suku Dayak yang berada di Kalimantan, melainkan sebuah nama yang mengandung filosofis sebagai falsafah hidup yang dianutnya. Puji- pujian dalam ritual Ngaji Rasa ini terdiri atas tiga judul puji-pujian, yakni Puji-pujian Ana Kita Ana Sira, Puji-pujian Alam Segandhu, dan Puji-pujian Anak Kembar Jaya. Puji-pujian tersebut dilantunkan sebagai pembuka ritual Ngaji Rasa, biasanya dilantukan dengan irama yang sama dengan penuh kekhusyukan. Puji-pujian ini merupakan bentuk bahasa yang hidup dalam komunitas SDHBBSI yang membuktikan bahwa bahasa dan budaya memiliki suatu keterkaitan. Puji-pujian ini menggambarkan adanya nilai-nilai kearifan lokal yang terkandung di dalamnya. Keraf (2010), menyebutkan bahwa kearifan lokal (local wisdom) sebagai sarana pencerdasan adalah semua bentuk pengetahuan, keyakinan, pemahaman, pemahaman atau wawasan serta adat kebiasaan atau etika yang menuntun perilaku manusia dalam kehidupan di dalam komunitas ekologis.

Salah satu contoh larik yang menunjukkan adanya bentuk nilai-nilai kearifan lokal dalam puji-pujian ritual Ngaji Rasa adalah Ana Kita Ana Sira, Wijile kita tukule sira (Ada saya ada kamu, lahirnya saya tumbuhnya kamu). Dalam penggalan tersebut tersirat suatu nilai kearifan lokal yang memperlihatkan adanya kedekatan antara anggota SDHBBSI dengan alam karena penggunaan kata wijil dan tukul adalah leksikon-leksdikon tumbuhan. Adanya leksikon tumbuhan pada larik wijile kita tukule sira ini bila diterjemahkan artinya lahirnya saya tumbuhnya kamu yang memiliki arti dari rahim seorang ibu, anak dilahirkan ke dunia. Dalam puji-pujian tersebut terkandung nilai yang diyakini kebenarannya dan menimbulkan tekad anggotanya untuk terus menjalankan nilainilai tersebut di tengah bergulirnya pro dan 
kontra terhadap ajaran yang dianut oleh komunitas SDHBBI.

Berdasarkan pandangan di atas, penelitian ini menjadi penting karena berkaitan dengan pewarisan pengetahuan lokal tentang semua konsep harmoni seperti yang telah dipaparkan di atas. Penelitian ini akan menggunakan kajian antropolinguistik. Antropolinguistik muncul sebagai kajian untuk mengungkap hal-hal yang berhubungan dengan kebudayaan dilihat dari kebahasaannya. Sibarani (2004) mengungkapkan bahwa antropolinguistik adalah cabang linguistik yang mempelajari variasi dan penggunaan bahasa dalam hubungannya dengan perkembangan waktu, perbedaan tempat komunikasi, sistem kekerabatan, pengaruh kebiasaan etnik, kepercayaan, etika berbahasa, adat istiadat, dan pola-pola kebudayaan lain dari suatu suku bangsa. Maka, istilah antropolinguistik dalam penelitian puji-pujian ini dititik beratkan pada kajian linguistiknya. Melalui studi antropolinguistik, ada beberapa hal penting yang dapat diungkap berkenaan dengan leksikon-leksikon yang terkandung dalam puji-pujian ritual Ngaji Rasa SDHBBI. Leksikon-leksikon dalam puji-pujian itulah yang menjadikan topik ini menarik dan penting untuk diteliti.

\section{MATERI DAN METODE}

\section{Materi}

\section{Kebudayaan dan Bahasa}

Manusia dalam menjalani kehidupannya tidak akan lepas dari berbagai macam kebutuhan hidup. Adanya kebutuhan hidup ini mendorong manusia untuk memenuhi segala macam kebutuhannya dengan melakukan berbagai bentuk aktivitas. Melihat fenomena tersebut, Ashley Montagu (dalam Sibarani 2004) mengatakan bahwa kebudayaan mencerminkan tanggapan manusia terhadap kebutuhan dasar hidupnya.

Menurut ilmu antropologi, kebudayaan adalah keseluruhan sistem gagasan, tindakan dan hasil karya manusia dalam rangka kehidupan masyarakat yang dijadikan milik diri manusia dengan belajar (Koentjaraningrat 2009). Secara pragmatis, kebudayaan adalah kebiasaan suatu masyarakat yang bermanfaat untuk mempertahankan dan mengembangkan cara hidupnya (Sibarani 2004). Dengan demikian, kebudayaan adalah keseluruhan kebiasaan kelompok masyarakat yang tercermin dalam pengetahuan, tindakan, dan hasil karyanya sebagai makhluk sosial yang digunakan untuk memahami lingkungannya dan yang menjadi pedoman tingkah lakunya untuk mencapai kedamaian dan/atau kesejahteraan hidupnya (Sibarani 2004).

Kebudayaan dan bahasa merupakan dua sisi mata uang yang berbeda, tetapi hubungan kedua hal tersebut tidak dapat dipisahkan karena bahasa merupakan cermin budaya dan identitas diri penuturnya. Sibarani (2004) menjelaskan bahwa bahasa juga memiliki semua karakteristik kebudayaan karena bahasa dimiliki seluruh anggota masyarakat; bahasa ditransmisi secara sosial; bahasa tercermin dalam ide, tindakan, dan hasil karya manusia; bahasa sebagai sarana manusia untuk berperan, bertindak, berinteraksi, dan berfungsi dalam kehidupan masyarakat; bahasa juga harus dipelajari; dan bahasa juga dapat membahagiakan masyarakat lewat pesan yang disampaikan.

Oleh karena itu, bahasa dapat mendeskripsikan budaya masyarakat pemakai bahasa tertentu dan melalui bahasanya tersebut kita dapat memahami budaya pemakai bahasa tersebut yang didalamnya terdapat cara berpikir masyarakat pengguna bahasa tersebut. Cara berpikir masyarakat pengguna bahasa tersebut mencakup pengetahuan yang dimilikinya, yaitu ciri-ciri material, manfaat yang diperoleh dari material, dan teknikteknik yang dapat dilakukan dalam memanfaatkan material-material tersebut. 


\section{Cermin Kearifan Lokal}

Rahyono (2009) menerangkan bahwa kearifan merupakan sesuatu yang dihasilkan dari sebuah kecerdasan manusia yang dapat digunakan oleh sesamanya sebagai sarana pencerdasan. Pemikiran dan sikap hidup manusia yang dilandasi kearifan mampu memberikan ketenteraman dan kebahagiaan hidup kepada sesama manusia dalam bermasyarakat. Salah satu cara untuk meningkatkan nilai-nilai luhur kemanusiaan perlu dibutuhkan usaha dan hasil usaha manusia dalam bermasyarakat yang dapat diartikan sebagai kebudayaan. Menurut Rahyono (2009), kearifan dalam suatu budaya yaitu seluruh usaha dan hasil usaha manusia yang dilakukan untuk memberikan makna manusiawi dan membuat tata kehidupan yang manusiawi pula.

Mengacu kembali pada definisi kearifan yang berarti kecerdasan, kearifan dalam budaya juga merupakan bentuk kecerdasan yang dihasilkan oleh masyarakat pemilik kebudayaan bersangkutan. Rahyono (2009) menyimpulkan bahwa sebuah kearifan lokal merupakan kecerdasan yang dihasilkan berdasarkan pengalaman yang dialami diri sendiri sehingga menjadi milik bersama. Selain itu, Keraf (2010) menyebutkan bahwa kearifan lokal (local wisdom) adalah semua bentuk pengetahuan, keyakinan, pemahaman atau wawasan, serta adat kebiasaan atau etika yang menuntun perilaku manusia dalam kehidupan di dalam komunitas ekologis.

Sejalan dengan Rahyono dan Keraf, Sunaryo dan Laxman (2003) mengatakan bahwa kearifan lokal merupakan pengetahuan lokal yang sudah demikian menyatu dengan sistem kepercayaan, norma dan budaya, serta diekspresikan di dalam tradisi dan mitos yang dianut dalam waktu yang cukup lama. Dari pengertianpengertian yang disebutkan sebelumnya tentang kearifan lokal dan kebudayaan, dapat ditarik simpulan bahwa kearifan lokal merupakan segala bentuk pengetahuan, adat istiadat, dan etika dalam suatu sistem nilai kelompok masyarakat yang akan mewujudkan

harapan-harapan

masyarakatnya.

\section{Metode}

\section{Metode Penelitian}

Penelitian mengenai puji-pujian dalam ritual Ngaji Rasa komunitas SDHBBSI ini menggabungkan dua unsur, yaitu budaya dan bahasa. Penelitian ini melibatkan dua disiplin ilmu yang saling berkesinambungan, yaitu linguistik antropologi (anthropological linguistics) dan antropologi linguistik (linguistic anthropology). Dalam penelitian ini akan diungkap nilai-nilai kearifan lokal yang terkandung dalam isi puji-pujian. Oleh sebab itu, penelitian ini menggunakan pendekatan antropolinguistik dengan metode etnografi komunikasi. Untuk mendukung metode penelitian deskriptif ini, peneliti melakukan penelitian secara kualitatif. Metode deskriptif analisis adalah metode dengan cara menguraikan sekaligus menganalisis untuk mendapatkan makna secara maksimal (Ratna 2010). Jadi, metode penelitian deskriptif-kualitatif dalam penelitian ini bertujuan untuk memperoleh data sebanyak-banyaknya agar didapat makna secara maksimal dalam menganalisis puji-pujian dengan mendeskripskan pujipujian. Selain itu, metode ini dilakukan untuk memahami fakta-fakta yang ada dibalik kenyataan yang dapat dilihat atau diinderai secara langsung karena pemahaman yang diperoleh melalui penelitian kebudayaan tidak datang dengan sendirinya ataupun dinyatakan langsung oleh realitas budayanya, tetapi direfleksikan, ditafsirkan atau diinterpretasikan, dan direkonstruksi oleh peneliti (Humaira 2015).

Pendeskripsian yang disajikan sesuai dengan pandangan hidup orang Jawa yang juga merupakan cerminan budaya pada komunitas SDHBBSI. Penelitian puji-pujian ini, tidak hanya pada tataran linguistik saja, melainkan melibatkan konteks budaya yang lebih luas lagi. Oleh karena itu, penelitian ini 
menggunakan model pendekatan etnografi komunikasi. Pada model pendekatan etnografi komunikasi, kajian dipusatkan untuk memfokuskan kerangka acuan karena pemberian tempat bahasa di dalam suatu kebudayaan bukan pada bahasa itu sendiri, melainkan pada komunikasinya (Hymes 1980). Model pendekatan etnografi komunikasi ini berfungsi untuk mengungkap nilai-nilai kearifan lokal pada puji-pujian ritual Ngaji Rasa yang mengacu pada pandangan hidup orang Jawa.

\section{Lokasi Penelitian}

Penelitian ini dilakukan di lingkungan komunitas SDHBBSI yaitu di Desa Krimun, Blok Tanggul, Rt. 13, Rw. 03, Kecamatan Losarang, Kabupaten Indramayu. Lokasi penelitian ini sengaja dipilih karena merupakan komunitas terbatas yang berusaha memunculkan dan menjaga nilainilai kearifan lokal yang dimilikinya.

\section{Teknik Pengumpulan Data}

Teknik Pengumpulan Data Dalam penelitian ini, peneliti menggunakan teknik dalam pengumpulan data. Teknik yang digunakan peneliti untuk memperoleh data adalah teknik observasi partisipan dan wawancara tidak berstruktur.

\section{Teknik Analisis Data}

Data-data yang didapat dari hasil pengumpulan data akan dianalisis melalui beberapa tahapan meliputi transkripsi data, terjemahan data, pengklasifikasian data, dan analisis data. Transkripsi data digunakan untuk menyalin tuturan puji-pujian lisan ke dalam bentuk tulisan yang kemudian dilakukan terjemahan data. Terjemahan data dilakukan untuk menerjemahkan bahasa Jawa ke dalam bahasa Indonesia sehingga mempermudah dalam melakukan pengolahan data ketahap berikutnya. Setelah itu, dilakukan analisis data untuk menjawab pertanyaan-pertanyaan yang terangkum dalam rumusan masalah yang kemudian disimpulkan menjadi hasil atau simpulan penelitian yang telah dilakukan.
Pada tahap analisis data, langkah pertama yang dilakukan adalah mentranskripsikan hasil rekaman pujipujian. Lirik puji-pujian akan dianalisis menggunakan model analisis bentuk, fungsi, dan makna (Ratna 2010). Analisis bentuk lirik puji-pujian meliputi formula sintaksis, diksi, dan tema. Selain itu, analisis manfaat dan fungsi akan digunakan untuk menjawab referensi leksikon yang terkandung dalam pujipujian ritual Ngaji Rasa. Selanjutnya, untuk mengetahui cermin kearifan lokal yang digunakan yakni berkaitan dengan bagaimana konsepsi-konsepsi pola pikir dan pandangan hidup orang Jawa terhadap kalimat-kalimat dalam teks puji-pujian.

\section{HASIL DAN PEMBAHASAN}

Berdasarkan deskripsi terhadap puji-pujian dalam ritual Ngaji Rasa Suku Dayak Hindu Budha Bumi Segandu Indramayu, dapat diketahui struktur teks puji-pujian dalam ritual Ngaji Rasa Suku Dayak Hindu Budha Bumi Segandu Indramayu, referensi leksikon puji-pujian dalam ritual Ngaji Rasa Suku Dayak Hindu Budha Bumi Segandu Indramayu, dan nilai kearifan lokal pujipujian dalam ritual Ngaji Rasa Suku Dayak Hindu Budha Bumi Segandu Indramayu. Berikut ini akan diuraikan pembahasan mengenai tigal hal tersebut.

\section{Struktur Teks Puji-pujian}

Berikut ini akan diuraikan pembahasan mengenai struktur teks puji-pujian ritual Ngaji Rasa komunitas SDHBBSI. Pembahasan struktur teks ini meliputi formula sintaksis sintaksis puji-pujian, diksi, dan tema.

\section{Formula Sintaksis}

Dalam analisis formula sintaksis ini, data yang dianalisis berjumlah tiga puji-pujian, yaitu puji-pujian Ana Kita Ana Sir, pujipujian Alam Bumi Segandu, dan puji-pujian Anak Kembar Jaya. Terdapat beberapa larik yang termasuk ke dalam klausa yang akan dianalisis berdasarkan fungsi, kategori, dan peran. Selain itu, larik-larik dalam puji- 
pujian ini dapat dianalisis berdasarkan Pemaparan ringkas analisis formula bentuk frasa yang terdapat di dalamnya. sintaksis terdapat pada Tabel 1.

Tabel 1 Analisis sintaksis puji-pujian Ana Kita Ana Sira

\begin{tabular}{llllll}
\hline \multicolumn{1}{c}{$\begin{array}{c}\text { Analisis } \\
\text { Sintaksis }\end{array}$} & \multicolumn{1}{c}{$\begin{array}{c}\text { Ana } \\
\text { (ada) }\end{array}$} & $\begin{array}{c}\text { Kita } \\
\text { (saya) }\end{array}$ & $\begin{array}{c}\text { Ana } \\
\text { (ada) }\end{array}$ & $\begin{array}{c}\text { Sira } \\
\text { (kamu) }\end{array}$ \\
\hline Fungsi & $\mathrm{P}$ & $\mathrm{S}$ & $\mathrm{P}$ & $\mathrm{S}$ \\
Kategori & $\mathrm{V}$ & $\mathrm{N}$ & $\mathrm{V}$ & $\mathrm{N}$ \\
Peran & Keberadaan & Pelaku & Keberadaan & Pelaku \\
\hline
\end{tabular}

Pada larik ke-1 (Tabel 1) terdiri atas empat kata, yakni ana (ada), kita (ada), ana (ada), dan sira (kamu). Dalam larik ini fungsi predikatnya adalah kata ana. Kata ana ini berkategori verbal atau yang disebut kata kerja. Kata ana merupakan predikat yang memiliki peran sebagai makna keberadaan. Untuk membuktikan suatu predikat menyatakan peran atau makna keberadaan yakni dengan cara menguji kata yang berfungsi predikat tersebut dengan sebuah pertanyaan dimana?. Makna fungsi predikat kata ana ini menerangkan bahwa makna keberadaannya ada di kata kita dan sira. Kata kita dan sira dalam larik pertama komunitas SDHBBSI ini, menggambarkan adanya keberadaan yang selaras bahwa adanya anak itu karena keberadaan orang tua.

Tabel 1 merupakan contoh analisis formula sintaksis, pada analisis formula sintaksis dari tiga puji-pujian. Pada pujipujian Ana Kita Ana Sira terdapat 24 tabel analisis sintaksis, pada puji-pujian Pujian Alam Segandu terdapat 20 tabel analisis sintaksis, dan pada puji-pujian Anak Kembar Jaya terdapat 10 tabel. Analisis tabel tersebut berdasarkan klausa yang terdapat dalam puji-pujian, sehingga analisisnya tidak dilakukan perlarik.

\section{Diksi}

Penggunaan bahasa dalam puji-pujian ritual Ngaji Rasa komunitas Suku Dayak Hindu Budha Bumi Segandu Indramayu ini menggunakan bahasa Jawa. Dalam pujipujian ritual Ngaji Rasa ini terdapat hal menarik yang berkaitan dengan penggunaan diksinya. Hal-hal berkaitan dengan pemilihan diksi dalam ini sangat terlihat jelas yakni adanya beberapa diksi yang muncul dan menggambarkan adanya makna tertentu dari komunitas SDHBBSI. Berikut analisis diksi yang terdapat dalam pujipujian Ana Kita Ana Sira.

Dalam puji-pujian Ana Kita Ana Sira ini terdapat pemilihan diksi Rohbana ya Rohbana, pada puji-pujian Pujian Alam Segandu terdapat pemilihan diksi darma $a y u$, dan pada puji-pujian Anak Kembar Jaya terdapat pemilihan diksi nur alam. Diksi tersebut merupakan salah satu contoh diksi yang ditemukan. Sesuai dengan kesimpulan yang diturunkan oleh Keraf (2010), pemilahan-pemilihan diksi ini dapat merujuk kepada adanya makna dari gagasan yang ingin disampaikan komunitas SDHBBSI.

Selain pemilihan diksi, repetisi (pengulangan) kata dalam puji-pujian ritual Ngaji Rasa ini memiliki banyak pengulangan. Berikut repetisi (pengulangan) yang ditemukan dalam pujipujian ritual Ngaji Rasa komunitas Suku Dayak Hindu Budha Bumi Segandu Indramayu.

1. Repetisi Anaforamesodiplosis

2. Repetisi Eefistrofis

3. Repetisi Anafora

4. Repetisi Tautotes

5. Repetisi Anadiplosis

\section{Tema}

Pada analisis tema ini, akan menyebutkan dan membahas tema yang terkandung dalam puji-pujian ritual Ngaji Rasa. Cara 
untuk menyingkap tema atau makna apa yang terkandung di dalam puji-pujian ini adalah dengan cara menemukan isotopi dan motif yang ada. Berikut isotopi-isotopi dan motif dalam puji-pujian ritual Ngaji Rasa.

Isotopi-isotopi pada puji-pujian dalam ritual Ngaji Rasa komunitas Suku Dayak Hindu Budha Bumi Segandu Indramayu.

Adapun penemuan isotopi-isotopi dalam puji-pujian tersebut yaitu isotopi manusia, arah, bilangan, letak, permohonan, alam, gagasan, aktifitas, kekuatan, permohonan, dan penghormatan. Isotopi manusia tergambar pada diksi kita, sira, ema, bapa, wong, wong tua, anak kembar, dan Nyi Ratu. Isotopi arah tergambar pada diksi wetan, kulon, elor, dan kidul. Isotopi bilangan tergambar pada kata bilangan lima. Isotopi permohonan tergambar pada diksi rohbana ya rohbana, sabarana, jujurana, benerana, uripana, warasana, cukulanan, bagusana, openana, nerima, dan openana. Isotopi alam tergambar pada diksi alam buana, alam bumi segandu, wijile kita, ana nur alam, dan ana alam. Isotopi gagasan terdapat pada diksi Indramayu gelaran Jawa, Jawa agama agama Jawa, Indramayu darma ayu darmane wong tua, wong tua anane ning awake sira. Isotopi kekuatan tergambar pada diksi kembar jaya, nur alam, dan Nyi Ratu. Serta, isotopi penghormatan tergambar pada diksi anak nggolati wong tua dan Nyi Ratu Kembar Jaya.

Isotopi-isotopi pada puji-pujian dalam ritual Ngaji Rasa ini dapat menghasilkan suatu tema yang menonjol dalam isi pujipujian. Tema akan terlihat setelah ditemukan motif dari kumpulan isotopiisotopi. Berikut adalah motif dan tema yang tergambar dari leksikon puji-pujian dalam ritual Ngaji Rasa. Pada puji-pujian Ana Kita Ana Sira terdapat adanya motif kehidupan, aktifitas, dan tujuan yang menjelaskan tema puji-pujian ini berkaitan dengan pesan dan ajaran orang tua kepada anaknya untuk menjalani hidup sesuai semestinya dengan baik. Pada puji-pujian Alam Segandu terdapat motif kehidupan dan motif gagasan yang menjelaskan tema puji-pujian berkaitan dengan isi-isi mengenai sejarah alam bumi segandu dan jawa agama yang dijadikan sebagai pedoman hidup. Lalu, pada puji-pujian Anak Kembar Jaya terdapat motif kehidupan, gagasan, aktifitas, dan penghormatan yang menjelaskan tema keberadaan anggota SDHBBSI di bumi segandu dan sosok Nyi Ratu yang dipercayai memiliki kekuatan dan harus dihormati setinggi-tingginya yang dicerminkan ada di dalam diri orang tua.

\section{Referensi Leksion Puji-pujian dalam Ritual Ngaji Rasa Suku Dayak Hindu Budha Bumi Segandu Indrmayu}

Referensi leksikon dalam puji-pujian Ritual Ngaji Rasa Suku Dayak Hindu Budha Bumi Segandu Indramayu dapat digolongkan menjadi bermacam-macam, yakni (1) permohonan, (2) ketuhanan, (3) manusia, (4) kekerabatan, (5) aktifitas, (6) tempat, (7) alam, dan (8) nasihat.

Pada puji-pujian ritual Ngaji Rasa ini menunjukkan beberapa referensi leksikon yang dikerucutkan menjadi makna bersama, seperti dalam leksikon permohonan menunjukkan adanya nuasa permohonan yang kuat seperti salah satunya pada leksikon rohbana ya rohbana. Leksikon ketuhanan mengacu pada hubungan roh-roh gaib yang dianggap sebagai sosok yang diagungkan seperti leksikon, Nyi Ratu. Leksikon yang menggambarkan referensi alam dalam puji-pujian ini adalah leksikon wijile, alam, alam buana, alam bumi segandu, bumi segandu Indramayu, bumi segandu, alam nur alam, dan bumi. Leksikon yang mencerminkan referensi kekerabatan dalam puji-pujian ini adalah leksikon ema (ibu), bapa (bapak), anak, dan wong tua (orang tua). Dari analisis data di atas, menggambarkan bahwa komunitas SDHBBSI diumpamakan sebagai anak yang begitu menghormati sosok orang tua yang terdiri atas ibu dan bapak. Leksikon yang mencerminkan referensi tempat dalam pujipujian ini adalah leksikon ning dunia, wetan, kulon, kidul, elor, duwur, esor, tengah-tengah, ning alam buana, alam bumi segandu, ning Indramayu, ning bumi segandu Indramayu, dan ning Dermayu. Leksikon yang 
mencerminkan referensi aktifitas dalam puji-pujian ini adalah leksikon nggolati dan mlayu. Leksikon-leksikon ini merupakan kata kerja atau verbal karena menerangkan sebuah aktifitas, kata nggolati artinya mencari dan kata mlayu artinya berlari. Terakhir, leksikon nasihat Leksikon yang mencerminkan referensi nasihat dalam pujipujian ini adalah leksikon lakonana, ayu niburi, dan ayu sira melu. Leksikon-leksikon ini berupa leksikon yang memiliki tujuan untuk mengajak dan memberikan masukan bagi anggota SDHBBSI agar melakukan halhal yang bersifat baik.

\section{Cermin Kearifan Lokal pada Puji- pujian dalam Ritual Ngaji Rasa}

Puji-pujian dalam ritual Ngaji Rasa komunitas Suku Dayak Hindu Budha Bumi Segandu Indramayu merupakan bagian dari kesatuan pemikiran komunitas SDHBBSI. puji-pujian sebagai bentuk komunikasi antarmanusia dengan alam semesta merupakan suatu kearifan lokal yang dimiliki oleh komunitas SDHBBSI. Berikut cermin kearifan lokal yang terkandung dalam puji-pujian ritual Ngaji Rasa komunitas SDHBBSI.

\section{Cermin Kearifan Lokal Hubungan Manusia dengan Tuhan}

Terdapat cermin nilai kearifan lokal yang menyatakan hubungan manusia dengan Tuhan. Pada larik rohbana ya rohbana tercermin adanya suatu kesakralan, larik rohbana ya rohbana ini memiliki hubungan dengan larik selanjutnya yakni robah ena batin kita. Dalam larik ini, tercermin adanya suatu permohonan yang dilakukan oleh anggota SDHBBSI terhadap sosok yang mereka percayai dan mereka agungkan yang memiliki kedudukan yang sama dengan Tuhan yang diyakini oleh masyarakat pada umumnya.

Pada larik selanjutnya yakni ning dunia benerana, sabarana, jujurana, uripana, warasana, cukulana, openana, bagusana, sabarana ana kita, jujurana ana kita, benerana ana kita, dan nerima ana ana kita ini sama seperti larik sebelumnnya yang menunjukkan adanya permohonanpermohonan yang dilakukan oleh anggota SDHBBSI terhadap sosok yang mereka percayai dan mereka agungkan yang memiliki kedudukan yang sama dengan Tuhan yang diyakini oleh masyarakat pada umumnya.

Pada larik pujian Anak Kembar Jaya terdapat cermin nilai kearifan lokal yang menyatakan hubungan manusia dengan Tuhan. Pada larik Nyi Ratu Kembar Jaya menggambarkan sosok perempuan yang dijadikan sumber kebenaran hidup yang harus dipuja dengan cara Ngaji Rasa. Sosok Nyi Ratu memiliki kedudukan yang sangat penting yang harus benar-benar dijaga dan dihormati. Oleh karena itu, nilai kearifan lokal selain mencerminkan hubungan manusia dengan Tuhan juga memberikan nilai-nilai untuk berbakti terhadap perempuan.

\section{Cermin Kearifan Lokal Hubungan Manusia dengan Alam}

Pada larik puji-pujian Ana Kita Ana Sira terdapat cermin nilai kearifan lokal yang menyatakan hubungan manusia dengan alam. Pada larik wijile kita tukule sira ini menggambarkan adanya nilai kearifan lokal yang mencerminkan kedekatan antara anggota SDHBBSI dengan alam, karena penggunaan kata wijil dan tukul yang identik dengan leksikon-leksikon tumbuhan. Adanya penggunaan leksikon tumbuhan pada larik wijile kita tukule sira ini bila diterjemahkan artinya bijinya saya tumbuhnya kamu yang memiliki arti dari rahim seorang ibu anak dilahirkan ke dunia.

Larik berikutnya yang mencerminkan adanya nilai kearifan lokal hubungan manusia dengan alam yakni leksikon wetan, kulon, kidul, elor, duwur, esor, dan tengahtengah. Leksikon tersebut menggambarkan leksikon arah dan letak yang ada di alam bumi ini. Penggunaan leksikon-leksikon tersebut mencerminkan adanya kedekatan antara anggota SDHBBSI dengan alam. Nilainilai kearifan lokal yang dicerminkan dari 
leksikon pada larik tersebut adalah adanya keselarasan dimana ada timur pasti ada barat, ada utara pasti ada selatan, dan ada atas pasti ada bawah. Anggota SDHBBSI ini tidak mempermasalahkan keberadaan mereka ada di posisi yang mana karena yang pasti mereka berada dan tinggal di tengah-tengah dari semua arah itu yaitu di tengah-tengah alam semesta.

\section{Cermin Kearifan Lokal Hubungan Manusia dengan Manusia}

Pada larik Indramayu darma ayu darmane wong tua ini menggambarkan adanya nilai kearifan lokal yang mencerminkan hubungan anggota SDHBBSI dengan manusia yang tergambar dalam frasa wong tua, karena penggunaan frasa darma ayu yang bermakna filosofis adanya gagasan yang ingin disampaikan oleh anggota SDHBBSI. Frasa Darma Ayu ini mencerminkan ajaran komunitas SDHBBSI ini mengacu pada orang tua perempuan yang disebut dengan ibu. Komunitas SDHBBSI ini mengartikan darma sebagai orang tua dan ayu sebagai perempuan.

\section{KESIMPULAN DAN IMPLIKASI}

\section{Kesimpulan}

Puji-pujian dalam ritual Ngaji Rasa ini, terdiri atas tiga judul puji-pujian, yaitu pujipujian Ana Kita Ana Sira, uji-pujian Alam Segandhu, dan uji-pujian Anak Kembar Jaya. Puji-pujian tersebut dilantunkan sebagai pembuka ritual Ngaji Rasa dan biasanya dilantunkan dengan irama yang sama dengan suasana yang sangat khusyu. Pujipujian ini merupakan bentuk bahasa yang hidup dalam komunitas SDHBBSI yang membuktikan bahwa bahasa dan budaya memiliki suatu keterkaitan. Puji-pujian ini menggambarkan adanya nilai-nilai kearifan lokal yang terkandung di dalamnya. Pujipujian ini dianalisis berdasarkan hal sebagai berikut.

Struktur teks puji-pujian dalam ritual Ngaji Rasa pada Komunitas Dayak Bumi Segandu Indramayu dihasilkan analisis formula sintaksis, pemilihan diksi dengan adanya pengulangan yang sangat kental dalam puji-pujian diantaranya pengulangan atau repetisi anaforamesodiplosis, efistrofis, anafora, tautotes, dan anadiplosis. Adapun penemuan isotopi-isotopi dalam puji-pujian tersebut yaitu isotopi manusia, arah, bilangan, letak, permohonan, alam, gagasan, aktifitas, kekuatan, permohonan, dan penghormatan. Isotopi-isotopi tersebut menghasilkan motif yang menjelaskan tema-tema puji-pujian. Dalam puji-pujian tersebut tema yang kuat adalah mengenai pesan, nasihat dan ajaran orang tua, isi seputar sejarah Indramayu, serta penghormatan tertinggi komunitas SDHBBSI terhadap sosok perempuan.

Referensi leksikon puji-pujian dalam ritual Ngaji Rasa pada Komunitas Dayak Bumi Segandu Indramayu menunjukkan adanya makna bersama. Dalam referensi leksikon puji-pujian terdapat beberapa referensi leksikon, yaitu permohonan, ketuhanan, alam, kekerabatan, tempat, aktifitas, dan nasihat.

Cermin kearifan lokal puji-pujian dalam ritual Ngaji Rasa pada Komunitas Dayak Bumi Segandu Indramayu sesuai dengan pandangan hidup orang jawa yang disebut dengan hubungan mikrokosmos dan makrokosmos. Dalam pencerminan nilai kearifan lokal dalam puji-pujian ini terbagi menjadi tiga bagian, yakni cermin nilai kearifan lokal hubungan manusia dengan Tuhan, cermin nilai kearifan lokal hubungan manusia dengan alam, dan cermin nilai kearifan lokal manusia dengan manusia. Ketiga cerminan nilai kearifan lokal tersebut mencerminkan adanya harmoni dan keselarasan sesuai dengan pandangan hidup orang Jawa.

\section{Implikasi}

Berdasarkan hasil penelitian dan kesimpulan yang telah diuraikan sebelumnya, maka implikasi dari penelitianini diharapkan para civitas akademika maupun masyarakat setempat turut mengenal dan mengetahui kebudayaan yang terdapat di sekitarnya, 
seperti kebudayaan yang terdapat pada komunitas Suku Dayak Hindu Budha Bumi Segandu Indramayu. Selain itu, pelestarian bahasa yang digunakan dalam setiap larik puji-pujian dapat dimaknai secara mendalam karena mencerminkan kebudayaan suatu masyarakat dan memiliki nilai-nilai luhur yang perlu dijunjung kelestariannya.

\section{DAFTAR PUSTAKA}

Humaira MA. 2015. Legenda Batu Hiu: analisis struktur, konteks penutur, fungsi, dan makna. Didaktika Tauhidi Jurnal Pendidikan Guru Sekolah Dasar Volume 2 Nomor 2.

Hymes D. 1980. Foundations in sociolinguistics: an ethnographics approach. University of Pennsylvania Press, Philadelpia.

Koentjaraaningrat. 2009. Pengantar ilmu antropologi. Rineka Cipta, Jakarta.

Kridalaksana H. 2001. Kamus linguistik. Gramedia Pustaka Utama, Jakarta.

Rahyono FX. 2009. Kearifan budaya dalam kata. Wedatama Widya Sastra, Jakarta.

Ratna NK. 2010. Metodologi penelitian: kajian budaya dan ilmu-ilmu sosial humaniora pada umumnya. Pustaka Pelajar, Yogyakarta.

Sibarani R. 2004. Antropolinguistik: Antropologi Linguistik, Linguistik Antropologi. Poda, Medan.

Sunaryo dan J Laxman. 2003. Peranan pengetahuan ekologi lokal dalam sistem agroforestry. World Agroforestry Center (ICRAF) Southeast Asian Regional Office, Bogor. 